\title{
Defending and contesting the sovereignty of law: the public lawyer as interpretivist
}

Article

Accepted Version

Lakin, S. (2015) Defending and contesting the sovereignty of law: the public lawyer as interpretivist. Modern Law Review, 78 (3). pp. 549-570. ISSN 0026-7961 doi:

https://doi.org/10.1111/1468-2230.12128 Available at https://centaur.reading.ac.uk/39402/

It is advisable to refer to the publisher's version if you intend to cite from the work. See Guidance on citing.

To link to this article DOI: http://dx.doi.org/10.1111/1468-2230.12128

Publisher: Wiley

All outputs in CentAUR are protected by Intellectual Property Rights law, including copyright law. Copyright and IPR is retained by the creators or other copyright holders. Terms and conditions for use of this material are defined in the End User Agreement.

\section{www.reading.ac.uk/centaur}

\section{CentAUR}

Central Archive at the University of Reading

Reading's research outputs online 


\title{
REVIEW ARTICLE
}

\section{Defending and Contesting the Sovereignty of Law: the Public Lawyer as Interpretivist}

\author{
Stuart Lakin* \\ T. R. S. Allan, The Sovereignty of Law Freedom, Constitution and Common Law, Oxford \\ University Press, 2013, 361pp, hb £53.00.
}

How do we determine the content of the law and the constitution in Britain - the legal and constitutional (or conventional) rights, duties and powers of individuals, officials and institutions?

On one view, favoured by many UK public lawyers, we simply consult the relevant empirical facts: the rule(s) that identify the sources of law within the constitution, the intentions of parliament in its statutes, the rules of statutory interpretation, the dicta of judges, and the standards of conduct that officials have accepted as binding in their political practices. In short, we describe the law and the constitution in much the same way as an anthropologist describes human behaviour, or an astronomer describes the arrangement of the planets. What we do not do is engage in controversial debates about the meaning and requirements of moral values such as the rule of law, democracy and liberty. Such debates, on this view, are not pertinent to the question of what the content of the law and the constitution is, but only to what it should be. Other people turn that empirical fact thesis (EFT) on its head. They say that the content of the law and the constitution depends on controversial arguments of political morality. Judges and lawyers must interpret statutes, precedents and political practices in the light of the values and principles that best justify those provisions and which best justify the legal and constitutional order as a whole. On this view, every statement of the law and the constitution is the product of an interpretative judgment about which values and principles generate which rights, duties and powers. This interpretative thesis (IT) denies that the content of the law and the constitution depends wholly on empirical facts. It holds that the public lawyer - in common with judges, practitioners and citizens - must argue like a philosopher, rather than describe like a social scientist.

In his most recent book, The Sovereignty of Law Freedom, Constitution and Common Law (Sovereignty), Professor T R S Allan offers a robust defence of the second of these answers to the question posed above. He contends that constitutional argument can only be interpretative. He thinks that the EFT is misconceived. These methodological claims permeate his wide-ranging discussions of substantive issues in British constitutional law and practice. He also devotes his final chapter to an extended philosophical consideration of them. All that said, Sovereignty is not primarily a work in abstract constitutional methodology. Allan's motivating concern is a very practical one. He thinks that the traditional doctrine of parliamentary sovereignty and other tenets of British constitutional orthodoxy are incorrect because they are based on the EFT. Conversely, he thinks that his distinctive theory of common law constitutionalism, based on a liberal, republican-inspired, conception of the rule of law, is correct because it reflects the IT. His position seems to be this: if public lawyers argue in the correct (i.e. interpretative) way about the British constitution, then they must 
reject the traditional model of absolute legislative power in favour of a model of limited power or 'legitimate authority'. ${ }^{1}$

Whether or not one accepts Allan's methodological claims, or the way he marries them to particular visions of the constitution, he deserves high praise for approaching public law in this way. Over many decades, he has underlined the need for public lawyers to engage with deeper debates in legal and political theory. ${ }^{2}$ Above all, he has insisted that supporters of constitutional orthodoxy explain and justify their position - rather than dogmatically assume its correctness. The chapters of Sovereignty carry these messages forward with greater force and philosophical rigour than anything he has previously written. As impressive as the substance of his arguments is the way that he conveys them. Allan has a rare gift for bringing complex theories to life with clear and provocative analyses of cases and contemporary constitutional issues. Indeed, one would get a very good sense of his EFT/IT distinction just by reading a selection of these analyses and nothing else. His discussions of Liversidge (21-25), ${ }^{3}$ Prolife (25-31), ${ }^{4}$ Factortame $(\text { No } 1)^{5}$ and $(\text { No } 2)^{6}$ and Thoburn ${ }^{7}$ (14650), Jackson (150-153), ${ }^{8} R \vee A$ (No 2) (186-188), ${ }^{9}$ and Bancoult (chapter 8 generally), ${ }^{10}$ are particularly illuminating. This is an unashamedly theory-heavy work, but it is one that will resonate with the most theory-averse 'black letter' public lawyer, and even with students finding their way into their constitutional law module. ${ }^{11}$

I shall pursue two general objections to Allan's arguments in this review article, along with some incidental ones. The first objection relates to his EFT/IT distinction. I shall urge him to confront the EFT (which, I shall suggest, is really a large and varied number of different theses) as a rival to the IT, rather than dismiss it as the wrong type of argument. This is to say that his objection to descriptive accounts of the constitution is better understood as a substantive rather than methodological one. It concerns, I shall say, a difference in moral conviction about the proper role and importance of law and the rule of law within the constitution. Allan makes a compelling case for the 'sovereignty' of law as a guarantor of liberty and equal dignity. But those who support the EFT typically ascribe a narrower, communicative, function to law; and they see the rule of law as one value among a plurality of other, equally important values. The virtue of the interpretative method, as elaborated by Ronald

\footnotetext{
*Lecturer in Law, University of Reading. I am extremely grateful to Trevor Allan, Dimitrios Kyritsis and an anonymous reviewer for their challenging and gracious comments.

${ }^{1}$ Sovereignty 120.

${ }^{2}$ See, in particular, his earlier books: Law, Liberty and Justice: The Legal Foundations of British Constitutionalism (Oxford: Clarendon, 1993); Constitutional Justice: A Liberal Theory of the Rule of Law, (Oxford: Oxford University Press, 2001).

${ }^{3}$ Liversidge v Anderson [1942] AC 206

${ }^{4} R$ (Prolife) Alliance) v British Broadcasting Corporation [2002] EWCA Civ 297, [2003] UKHL 23.

${ }^{5} R v$ Secretary of State for Transport, ex p Factortame Ltd [1990] 2 AC 85.

${ }^{6} R v$ Secretary of State for Transport, ex p Factortame Ltd (No 2) [1991] 1 AC 603.

${ }^{7}$ Thoburn v Sunderland City Council [2002] EWHC 195 (Admin).

${ }^{8} R$ (Jackson) v Attorney General [2005] UKHL 56.

${ }^{9} R \cup A$ (No 2) [2001] UKHL 25.

${ }^{10} R$ (Bancoult) $v$ Secretary of State for Foreign and Commonwealth Affairs [2001] QB 1067, [2008] UKHL 61.

${ }^{11}$ Allan makes a point of beginning each chapter with an accessible overview of the detailed arguments that follow. See Sovereignty 15.
} 
Dworkin, is that it allows for genuine disagreement between fundamentally different theories such as these. ${ }^{12}$ I think this potential is regrettably lost in Sovereignty.

Secondly, I shall argue that Allan is caught between a rock and a hard place in his account of constitutional interpretation. If his position is that the British constitution - and constitutions in general - must be interpreted in line with his liberal theory of the rule of law, then this is no kind of interpretation at all: the content of the law and the constitution will be the same irrespective of the particular legislative and judicial decisions that (supposedly) form the object of interpretation. If, on the other hand, he proposes his rule of law theory as the best interpretation of practice and principle in Britain, then there is arguably a problem of fit. His court-centric theory arguably underplays a range of constitutional features that point towards a greater role for the political branches of government. I have in mind, in particular, the scheme of the Human Rights Act 1998 (HRA 1998). The section 4 declaration of incompatibility - favoured by those who think Parliament should be the primary forum for rights protection - is almost invisible in Sovereignty. Allan sometimes seems to treat section 3 as the only constitutionally acceptable route for judges to take.

I shall structure this review in three parts. In the first part, I shall offer a summary of Allan's arguments. The following two parts will correspond to the two general objections just described.

\section{ALLAN'S METHODOLOGICAL AND SUBSTANTIVE ARGUMENTS}

At the foundations of Allan's argument in Sovereignty is his rejection of the EFT (the empirical fact thesis), and his advocacy of the IT (the interpretative thesis) as a method for determining the content of the law and the constitution in Britain. There are countless statements of this position throughout his chapters. Here are two particularly clear early examples:

'[W]e cannot identify the content of law with a merely descriptive account of judicial practice, viewed as a matter of empirical fact: it is a product of normative judgment in which we attempt to make good moral sense of an array of such familiar legal 'sources' as Acts of Parliament, judicial precedent and influential dicta. An account of English law on any specific subject is always a theory of how best to read the relevant legal materials, guided by notions of justice and coherence: we assume that law, correctly interpreted, should as far as possible serve the interests of justice, rather than injustice, and be broadly coherent rather than confused and contradictory. And this is true even when we disagree about what justice requires, or about what would make the law more coherent overall'. 13

and

\footnotetext{
${ }^{12}$ See, in particular, Ronald Dworkin, A Matter of Principle (Oxford: Clarendon Press, 1986); Law's Empire (London, Fontana, 1986); Justice in Robes (Cambridge, Mass: Harvard University Press, 2006); Justice for Hedgehogs (Cambridge, Mass: Harvard University Press, 2011).

${ }^{13}$ Sovereignty 5.
} 
'This book denies that there is any neutral, detached, descriptive ground on which a lawyer may stand in drawing conclusions about the requirements of English (or Scottish or European) law, in general, or the content of the British constitution, in particular. It insists that any statement of law is always a matter of interpretation, and that interpretation is (in the present context) necessarily normative: it draws on moral and political ideas and values to support one reading rather than another'. ${ }^{14}$

In advancing these methodological claims, Allan consciously takes sides in the stickiest of debates in legal theory. He is with the so-called 'anti-positivists' who contend a) that the content of the law depends, at least in part, on moral facts or principles, b) that judges should ordinarily decide cases according to law, c) that when judges and lawyers disagree, they are disagreeing about what the law is, and d) that citizens have a general duty to obey the law. He is against those positivists who contend a) that the content of the law is exhausted by empirical facts (typically about what particular people have said, thought, or written), b) that the moral questions of how judges should decide cases, and whether the law is just, are distinct from the question of what content the law has, c) that when judges and lawyers disagree, they are disagreeing about what the law should be, and d) that neither citizens nor judges have a general duty to obey (or enforce) the law. How we assess the overall arguments in Sovereignty will inevitably hang on what we make of this debate and Allan's treatment of it. My first general objection in the next section will take up this issue.

As one would expect, Allan applies these abstract philosophical puzzles to recognizable, concrete concerns. In the first place, he warns us about the greater or lesser practical significance of public law scholarship depending on which method is correct. If the IT is correct, then public lawyers' disagreements about the meaning and requirements of the rule of law, democracy, the separation of powers, and so on, are directly 'pertinen[t] to the administration of justice, as opposed to academic debate and criticism'. ${ }^{15}$ If the EFT is correct, then the opposite holds true: public law debates are peripheral to settled understandings of the law 'as it is'. ${ }^{16}$ Allan is understandably keen to show that works such as Sovereignty are as relevant to the day-to-day work of judges and lawyers as they are to Law Commission reports and student dissertations. Secondly, he sees the EFT/IT distinction as the key to settling the correct understanding of the contemporary British constitution. His view, in a sentence, is this: constitutional orthodoxy is flawed because it is based on a flawed method of argument, namely the EFT; common law constitutionalism is correct because is based on the correct method of argument, namely the IT.

What is not always entirely clear is the precise relationship Allan envisages between the IT and his own distinctive theory of common law constitutionalism and the rule of law. On the one hand, as we see from the passages quoted above, he does not seem to want to inject the IT with any particular scheme of 'moral and political ideas and values': he concedes that people will disagree 'about what justice requires, or what would make the law more coherent overall.' On the other hand, he sometimes seems to equate the IT with the particular values, basic liberties and institutional arrangements that belong to his theory of common

\footnotetext{
14 ibid 9.

15 ibid 4.

${ }^{16}$ ibid 5 .
} 
law constitutionalism and legality as independence. This tension comes out in the following recurrent claim:

'Any statement of law depends on our shared commitment to legality - a moral ideal connected to related ideals of freedom, justice and equality'. ${ }^{17}$

What does he mean by 'our shared commitment'? One possibility is that every interpretation of the constitution must be guided by the same abstract values, albeit that people may disagree about their precise meaning and requirements. This reading recalls Dworkin's theory of law as integrity: that the content of the law depends on whichever scheme of justice, fairness and due process is instantiated within the practice. ${ }^{18}$ On this understanding, we would say that Allan's own account of legality as independence is, in his view, the one that makes best moral sense of British constitutional practice. The second possibility is that everyone implicitly shares Allan's own detailed understanding of legality, freedom, justice and equality, such that all other ways of interpreting statutes, precedents and doctrines are mistaken. Each of these understandings throws up a number of practical and philosophical questions. This aspect of Sovereignty will be the focus of my second general objection in the last part of this article. Until then, I shall purposefully leave the meaning of the IT ambiguous between these two understandings.

Let us now look at Allan's theory of the rule of law, and at how this theory translates into an account of the British constitution. The rule of law (or legality), he says, is a 'basic principle of British government, underpinning its character as a liberal democratic polity'. ${ }^{19}$ It is an 'ideal of constitutionalism'. ${ }^{20}$ The particular conception of the rule of law that should (or must?) guide constitutional interpretation, he contends, is one

'...under which each person's freedom (or liberty) is secured, consistently with the enjoyment of a similar freedom for everyone. The kind of freedom I have in mind is autonomy or independence, understood as a guarantee against arbitrary interference - interference at the will or pleasure of other persons, whether private citizens or public officials, unregulated by legal rules enforced by independent courts'. ${ }^{21}$

This model of the 'rule of law as independence' is

'ultimately a principle of equal citizenship, precluding arbitrary distinctions between persons, irrelevant to any legitimate public purpose'. ${ }^{22}$ It '...imposes a requirement of justification, connecting restrictions on liberty to a public or common good, open to fearless public debate and challenge' ${ }^{23}$

Crucially, it is the responsibility of courts to articulate the precise requirements of equal citizenship through their common law decisions. And it is an 'inherent feature of the rule of

\footnotetext{
${ }^{17}$ ibid 8 .

${ }^{18}$ See, in particular, Dworkin, Law's Empire n 12 above, chs. 6 and 7. Allan regularly refers approvingly to Dworkin's theory of law as integrity. See, for example, Sovereignty 162-3 and the Appendix.

${ }^{19}$ Sovereignty 91.

${ }^{20}$ ibid 95.

${ }^{21}$ ibid 89.

${ }^{22}$ ibid 12.

${ }^{23}$ ibid 91 .
} 
law' that judges possess the power to quash a measure that cannot be interpreted in line with the rule of law. ${ }^{24} \quad$ It is in these senses that the Britain has a 'common law constitution'. While Allan clearly places much store in judges and courts, he is not straightforwardly advocating judicial supremacy or juristocracy. He frequently emphasizes that citizens must judge for themselves whether particular judgments (even of the Supreme Court), administrative decisions, Acts of Parliament, or the legal order as a whole contribute to the 'common good', such as to be worthy of their allegiance. ${ }^{25}$ And it is his enduring theme that the law depends both on ordinary democratic procedures and on the requirements of the rule of law. Neither parliament nor courts have the 'last word' on any matter. ${ }^{26}$ In these respects, he locates sovereignty in the individual bearer of rights, the constitution, and law, rather than in any particular institution. ${ }^{27}$

Allan develops and refines this account of the rule of law, the separation of powers and political obligation in the engine-room chapter of the book. ${ }^{28}$ Many readers will find much intrigue in his exegeses and adaptations of the work of Locke, Hayek, Dicey, Fuller, Dworkin and Kant, and in his invocation of the republican ideal of non-domination. ${ }^{29}$ One potentially fruitful line of inquiry - which I shall not pursue here - is whether nondomination is best secured by judges or by the political branches of government. Put differently, is it executive or judicial discretion that poses the greater threat to individual liberty and autonomy? Allan and Pettit ${ }^{30}$ think the former; others such as Bellamy think the latter. ${ }^{31}$ Suffice it to note, in anticipation of my arguments in the second section below, that particular political communities may adopt a variety of different institutional arrangements to secure individual liberty and autonomy (and/or other values). It would be a mistake, in my view, for Allan to attempt to homogenize all constitutions. ${ }^{32}$

Throughout Sovereignty, Allan works through the implications of his rule of law theory for the contemporary British constitution. His chapters all follow roughly the same structure. He connects some aspect of the British constitutional orthodoxy with the EFT. He explains (or recapitulates) what is wrong with the EFT and what is right about the IT. He then offers an alternative rule of law as independence reading of the relevant feature of legal or constitutional practice. Let me give some examples of this sequence, excluding for the moment his more abstract philosophical arguments against the EFT and for the IT. The examples follow roughly the order of his chapters. I shall mark against each substantive argument the method that Allan associates with it.

\footnotetext{
${ }^{24}$ ibid 37

${ }^{25}$ ibid $160-167$.

${ }^{26}$ ibid 133.

${ }^{27}$ ibid ch. 1 in general.

${ }^{28}$ ibid ch. 3 in general.

${ }^{29}$ The leading account is Philip Pettit, Republicanism: A Theory of Freedom and Government (Oxford: Clarendon Press, 1997).

${ }^{30}$ See Pettit op. cit.

${ }^{31}$ See Richard Bellamy, Political Constitutionalism: A Republican Defence of the Constitutionality of Democracy (Cambridge: Cambridge University Press, 2007). But Allan makes an interesting argument in his final chapter that Bellamy is in fact pro- judicial review. See Sovereignty 315-317. For an interesting reductio argument against judges having ultimate decision-making authority, see Jeffrey Goldsworthy, Parliamentary Sovereignty: Contemporary Debate (Cambridge: Cambridge University Press, 2010) 85.

${ }^{32}$ See section two below.
} 
(EFT) There is a clear distinction between law and constitutional convention, justiciable and non-justiciable powers, and the 'legal' and 'political' parts of the constitution. A norm is legal if it has been formally laid down by a legislature or court. A norm is conventional if politicians and statesmen have accepted it as binding in their political practices. Whether a norm is justiciable or not depends on the rules laid down by judges. Non-justiciable powers governed by constitutional convention comprise the 'political constitution'; justiciable powers governed by law comprise the 'legal constitution'. ${ }^{33}$

(IT) There is no clear distinction between law and convention: 'public law concerns the conduct of government; and legal interpretation cannot be divorced from political practice, whose principles and assumptions are necessarily pertinent to competent legal analysis'. ${ }^{34}$ The content of a constitutional convention depends on its underlying principle, context and purpose. ${ }^{35}$ There is no clear line between justiciable and non-justiciable areas of government: 'Justiciability cannot be settled by reference to judicial dicta in prominent cases: such dicta must be subjected to critical inquiry on the basis of legal principle, informed by a developed account of the central ideal of legality or the rule of law'. ${ }^{36}$ Legal and political practice are 'too intertwined and interdependent to sustain [a distinction between the legal and political constitution]. ${ }^{37}$

(EFT) The legal powers of Parliament and courts depend on the beliefs of most judges and officials, as evidenced by legal precedents and political practice. ${ }^{38}$ Most officials accept and have historically accepted that Parliament has absolute legislative power, and that courts cannot strike down legislation. This is the rule of recognition of the legal system. ${ }^{39}$ If Parliament were to pass a statute requiring the execution of blue-eyed babies, that statute would be legally valid, albeit that judges and citizens would have a moral duty to disobey it. $^{40}$

(IT) Parliament does not possess absolute legislative power. Legislative supremacy (Allan's preferred term) 'may [only] operate within the constitutional framework of the rule of law'. 'Parliament's authority is confined by the limits of our ability (in any concrete context) to interpret its enactments as contributions to the public good'. ${ }^{42}$ It follows that a statute is only recognisable as such if it can be read in a way that is compatible with the principle of equal citizenship and other rule of law values. ${ }^{43}$ The blue-eyed babies statute would be unlawful 'even if, absurdly, the Supreme Court affirmed it'. ${ }^{4}$

(EFT) Statutes communicate a 'speaker's meaning', the meaning that parliament intended. ${ }^{45}$ This intention may reflect the mental states of legislators, or the meaning that legislators

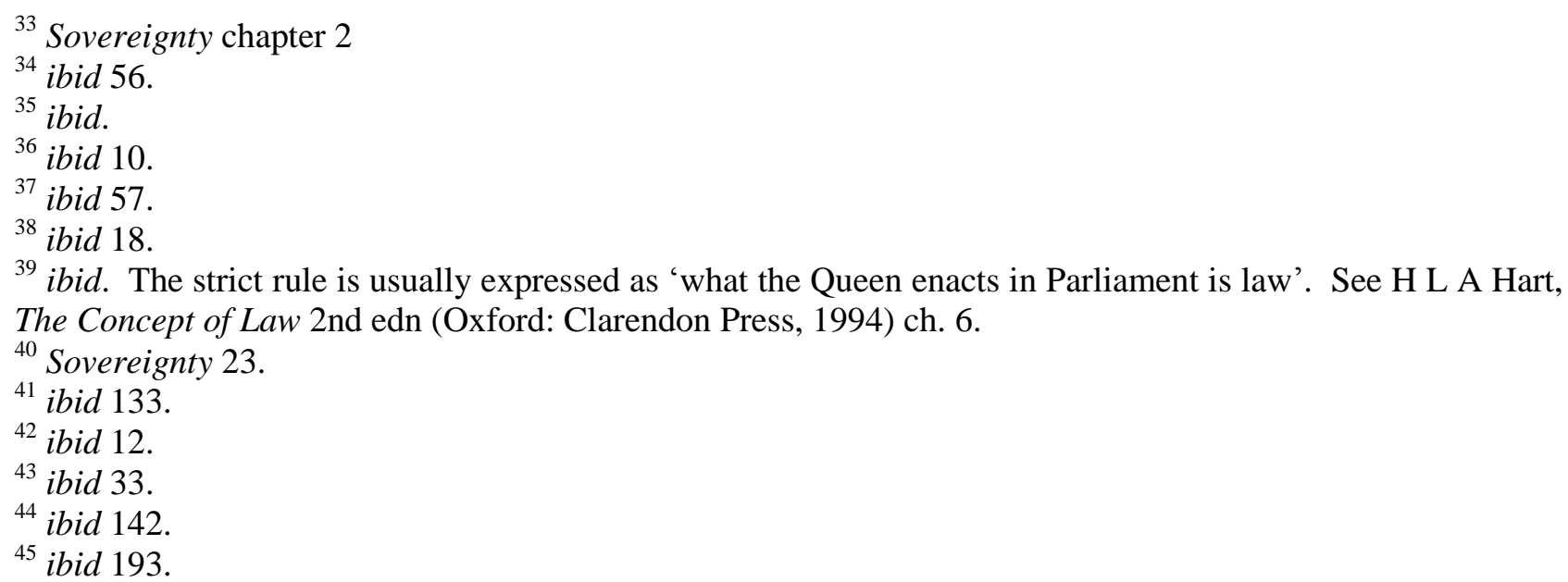


would have had had they put their minds to a particular problem, or the literal meaning of the statutory text.

(IT) The interpretation of a statute requires us to construct the intent of the 'ideal or representative legislator' who seeks to reconcile 'current policy and overarching legal principle'. ${ }^{46}$ There is then no conflict between Parliamentary supremacy and the rule of law, or between the ultra vires and common law theories of judicial review. These ideas are interdependent, embodying the twin imperatives of democracy and respect for individual dignity and autonomy. ${ }^{47}$

(EFT) The existence and content of the law is a separate concern to how judges should adjudicate on legal disputes. ${ }^{48}$ Judges have no general duty to apply the law. It may be appropriate for them to disregard the law, for instance, to promote democracy, institutional efficiency, comity, or justice. This extra-legal area of judicial decision making demands an independent doctrine of judicial deference. ${ }^{49}$

(IT) There is no independent doctrine of judicial deference. 'The relevant considerations of constitutional legitimacy and institutional expertise are already implicit constraints on judicial review - reflected in ordinary legal reasoning... ${ }^{50}$

This is just a flavour of the main arguments that appear in some of Allan's richly argued chapters. The various contrasting claims about the constitution will no doubt be familiar to public lawyers. What may be less familiar is the way that Allan pulls together these different substantive positions with different methods of constitutional analysis. As I have said above, this coupling of practice and theory is the defining virtue of Allan's work in general, but it is especially prominent in Sovereignty.

An important marker to lay down for our later discussions is that Allan's target in Sovereignty must be wider than the particular orthodox claims - and particular empirical facts on which those claims are based - outlined above. Given his wholesale rejection of the EFT, we must take Allan to be attacking any constitutional theory that makes the content of the law depend ultimately on empirical facts - whatever the relevant empirical facts might $b e$. This is important because many people who accept the EFT reject British constitutional orthodoxy or certain aspects of it. For example, Barber, applying the legal positivism of Joseph Raz, seeks to refute parliamentary sovereignty on the basis that European Community Law and parliamentary law both make conflicting claims to supremacy which cannot be settled by any ranking rules. ${ }^{51}$ His view is that the relative powers of Parliament and courts in the British constitution are legally indeterminate. Another way of putting the general point is that there are a plethora of different empirical fact theses (or different versions of

\footnotetext{
${ }^{46}$ ibid 194.

${ }^{47}$ ibid 168 and see ch. 5 in general.

48 ibid 6-7.

${ }^{49}$ See, for instance, Aileen Kavanagh, 'Defending Deference in Public Law and Constitutional Theory' (2010) 126 LQR 222-50.

${ }^{50}$ Sovereignty 241 and ch. 7 in general.

${ }^{51}$ See N W Barber, The Constitutional State (Oxford: Oxford University Press, 2010), chapters 9 and 10. See, further, Barber, 'Sovereignty Re-examined: the Courts, Parliament and Statutes' (2000) 20 OJLS 131154; 'The Afterlife of Parliamentary Sovereignty' 9 Int'l J. Const. L. (I.CON) (2011).
} 
legal positivism) which recommend diverse constitutional theories. ${ }^{52}$ Allan's argument must be that none of these theses and theories can elucidate the British constitution.

The question I have purposefully left hanging is why Allan thinks that the IT is correct and the EFT incorrect. (Actually, he uses rather stronger language than 'incorrect'. The descriptive method, he says, is 'dogmatic'; 53 and the orthodox claims that flow from it are 'simply confused and misguided'54). This question drills down to the foundations of Allan's edifice in Sovereignty. It challenges him to explain or justify his rejection of legal positivism in favour of anti-positivism. He responds with two arguments.

First, he contends that people who adopt the EFT misunderstand the true nature of legal and constitutional argument, where those who adopt the IT properly grasp it. He continually accuses EFT supporters of doing the wrong intellectual discipline. By treating statutes, precedents and political practices as 'social or psychological phenomena', they mistakenly take the detached, 'external point of view' of (for instance) an historian, political scientist or anthropologist. For Allan, the constitutional theorist must take up the same position as a judge or lawyer attempting to work out the content of the law in particular cases. She must take the morally engaged, 'internal perspective appropriate to an interpretation of the law' ${ }^{55}$ or appropriate to legal reasoning. This is to recognize that to be a lawyer is to be, at least in part, a legal philosopher... ${ }^{56}$ and that 'legal analysis cannot be detached from constitutional theory'. 57

At times, Allan reinforces this first argument in the following way. He claims that public lawyers who support the EFT have misappropriated theories of legal positivism which were not intended to be used as constitutional theories. He picks out, in particular, Goldsworthy's celebrated Hartian defence of parliamentary sovereignty. ${ }^{58}$ Hart famously characterized his seminal work the Concept of Law as an 'essay in descriptive sociology'.59 His aim, he explained, was to identify the main elements of law common to all legal systems at all times. ${ }^{60}$ At one point in his general argument, he remarks that the rule of recognition in England is 'what the Queen in Parliament enacts is law', understood as 'continuing' parliamentary sovereignty. ${ }^{61}$ Allan reasons that this reference to parliamentary sovereignty

\footnotetext{
${ }^{52}$ Equally, the same version of the EFT can generate a variety of different constitutional theories. Adam Tucker rejects absolute parliamentary sovereignty on the basis that the Hartian rule of recognition is indeterminate on the question of whether English law or EC law is supreme. See Tucker, 'Uncertainty in the Rule of Recognition and in the Doctrine of Parliamentary Sovereignty' (2011) 31 OJLS 61-88. Goldsworthy entertains the possibility that the empirical-fact-based rule of recognition might change from parliamentary sovereignty to something like common law constitutionalism. See Goldsworthy, Parliamentary Sovereignty above $\mathrm{n} 31,139-40$.

${ }^{53}$ Sovereignty 50.

${ }^{54}$ ibid 340.

55 ibid 32.

${ }^{56}$ ibid 9 .

${ }^{57}$ ibid 22.

${ }^{58}$ See Jeffrey Goldsworthy, The Sovereignty of Parliament: History and Philosophy (Oxford: Clarendon Press, 1999) especially chs. 1, 2 and 10; Goldsworthy, Parliamentary Sovereigty above n 31, 47-57.

${ }^{59}$ Above $\mathrm{n} 39$, preface.

${ }^{60}$ ibid ch. 1. For a very helpful analysis, see J Dickson, 'Methodology in Jurisprudence: A Critical Survey' Legal Theory 10 (2004) 117-156

${ }^{61}$ Hart above n 39, 74-78.
} 
is part of Hart's descriptive survey of legal systems, rather than a proper basis for a theory of the British constitution. In what I think is a wrong turning in Sovereignty, he charges Goldsworthy with 'taking refuge in bland sociological notion of law', 62 and 'hiding behind the attitude of senior officials'. ${ }^{63}$ I shall suggest in the next section below that Allan and Goldsworthy (and indeed Hart) have a genuine and important disagreement about law and the constitution, one that must ultimately be resolved at the level of political morality.

The second argument for the IT and against the EFT is based on evidence from a formidable range of case analyses. Allan's aim, it seems, is to show that judges do in fact reason interpretatively rather than descriptively when they decide cases. I shall give just one example of this strategy, highlighting in square brackets the different methods in play.

In Liversidge, ${ }^{64}$ the House of Lords had to determine the meaning of the phrase 'If the Secretary of State has reasonable cause to believe any person to be of hostile origin or associations he may order the detention of that person' ${ }^{65}$ The majority ruled that executive discretion was unfettered in the absence of proof of bad faith. On Allan's reading, Lord Atkin in his dissent 'appealed beyond the prevailing judicial consensus [EFT] to a vision of the constitution that afforded better protection of liberty [IT]' ${ }^{66}$ 'What may appear on a superficial reading to be a somewhat technical debate about language [EFT] - Atkin laid great emphasis on the ordinary legal implications of 'reasonable cause' - was in truth a more fundamental debate over the proper role of the judiciary' [IT]. 'Rival interpretations of law reflected deep-seated difference of constitutional vision: they exposed the gulf between underlying conceptions of the rule of law' [IT]. ${ }^{67}$ Lord Hoffmann was arguably wrong to assert in the later $A^{68}$ decision that Parliament suspended habeas corpus during the World Wars. ${ }^{69}$ This is so 'only by effect of the majority opinions in Halliday ${ }^{70}$ and Liversidge'. ${ }^{71}$ These are matters of 'legal interpretation [IT] rather than observable empirical fact [EFT]'. ${ }^{2}$

Note Allan's use of phrases such as 'what may appear on a superficial reading' and 'was in truth'. Elsewhere, he describes cases as being 'more plausibly' read in line with the IT than the EFT. ${ }^{73}$ We shall consider below whether he does enough to show that his IT reading of Liversidge and other cases (and of the constitution in general) is the true one, and other readings false.

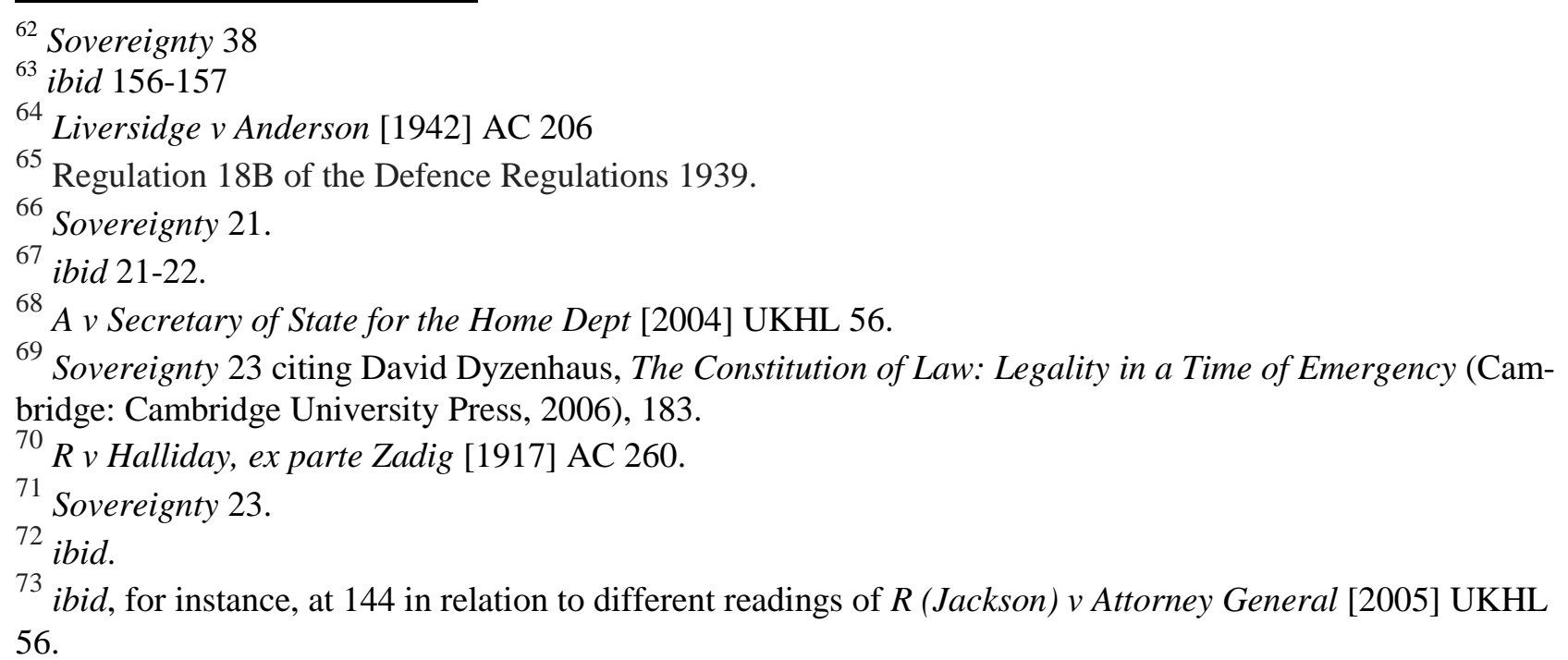


Having summarised Allan's main arguments, it is worth pausing to reflect on the scale of his ambition in Sovereignty. His primary target - the various tenets of British constitutional orthodoxy - is an understanding of the constitution that ostensibly attracts widespread support from judges, lawyers and officials, and which leading jurists and political philosophers have supported through the ages. ${ }^{74} \mathrm{He}$ is also attacking the popular and intuitively appealing view that the content of the law is determined by what legislators and judges have said, written, thought or believed. ${ }^{75}$ In place of this picture, he is proposing a radical (at least by the lights of the orthodoxy) reading of the British constitution with little explicit contemporary or historic support. He is also offering a somewhat counter-intuitive understanding of law. On his IT view, the content of the law may depend on principles which no legislator or judge has endorsed or even thought of. ${ }^{76}$ This means, he often stresses, that Supreme Court rulings may not reflect the true state of the law. ${ }^{77}$ It also means that the so-called 'unwritten' British constitution operates in much the same way as the written constitutions of the US and elsewhere. ${ }^{78}$ As if to raise the level of ambition higher still, he is not just saying that British constitutional orthodoxy (and other EFT accounts of the constitution) is incorrect, but that it is misconceived. He thinks that its supporters have fundamentally misunderstood how lawyers and judges really argue and decide cases: that they are busy doing sociology instead of legal and constitutional analysis.

\section{METHODOLOGICAL IMPASSE OR SUBSTANTIVE DISAGREEMENT?}

My first objection to Sovereignty picks up where the last section left off. It concerns Allan's reasons for rejecting the EFT in favour of the IT (and, by extension, his reasons for rejecting accounts of the constitution based on the EFT in favour of those based on the IT). On a strategic level, it must be said that Allan is unlikely to win over or engage his many public law adversaries with his methodological arguments. The natural response of EFT supporters will be to throw his arguments straight back at him. They will insist that it is he who has misunderstood the true (positivist) nature of law and adjudication; and they will insist that it is he, not they, who is doing the wrong intellectual discipline, namely mistaking a theory of the ideal constitution for the descriptive reality of the existing constitution. ${ }^{79}$ Similarly, they are unlikely to be convinced by Allan's case analyses. Even if they agree that there are practical or conceptual difficulties with the - rather primitive - version of the

\footnotetext{
${ }^{74}$ This is the 'historical' argument put forward by Goldsworthy in favour of parliamentary sovereignty. See, generally, above n 58. Cf Paul Craig, 'Public Law, Political Theory and Legal Theory' [2000] PL 211-39 (putting forward a competing historical argument in favour of the common law constitution).

${ }^{75}$ Allan grudgingly describes this view as the 'common sense' view. See Sovereignty 5.

${ }^{76}$ ibid 207.

77 ibid, for instance, at 6-7 and 142.

78 ibid 251, relying on Lord Hoffmann's celebrated dictum in $R v$ Secretary of State for the Home Dept, ex $p$ Simms [2000] 2 AC 115, 131. See, further, Jeffrey Jowell, 'Of Vires and Vacuums: The Constitutional Context of Judicial Review' [1999] PL 448-60.

${ }^{79}$ This is one way of understanding the exchanges between John Griffith and various common law constitutionalists. See, for instance, J. A. G. Griffith, 'The Brave New World of Sir John Laws' (2000) 63 MLR 159; 'The Common Law and the Political Constitution' (2001) 117 LQR 42-67. Similarly, see Dawn Oliver, 'Parliament and the Courts: A Pragmatic (or Principled) Defence of the Sovereignty of Parliament' in Alex Horne, Gavin Drewry and Oliver (eds) Parliament and the Law (Hart Publishing, 2013), 309-337, 321 (arguing that there is a gap between constitutional theory and practice).
} 
EFT that Allan associates with constitutional orthodoxy, there are countless alternative versions which they might summon in its stead. ${ }^{80}$ Drawing on more sophisticated positivist theories of law and adjudication, ${ }^{81}$ they might say that the content of the law depends on rules that are partly indeterminate, or which direct judges to reason morally (say, about the meaning of the separation of powers or proportionality). They might say that judges are guided by legal rules even when those rules do not directly control the case. They might say that the meaning of statutes is not determined by the mental states of legislators, or by the literal meaning of words, but by those rules and conventions of statutory interpretation that ensure that statutes communicate authoritatively.

If we return to Allan's analysis of Liversidge, we can certainly see how the IT fits the famous dissent of Lord Atkin. The question is whether Allan does enough to rule out an EFT reading of the court's reasoning. He may well persuade us that the disagreement of the judges was not a semantic one about the meaning of the phrase 'reasonable cause'; but that hardly exhausts the possible EFT readings. An EFT supporter might contend that the majority applied a legal rule or presumption, namely that legislation should not be read in accordance with the liberty of the subject during times of war. ${ }^{82}$ In that case, they will say, Lord Atkin's dissent amounted to a call for the majority to change or ignore that rule on extra-legal, moral, grounds. Alternatively, we might think that Lord Atkin's decision was correct, not on the IT basis that he was reasoning directly about liberty, the rule of law and the separation of powers, but on the EFT basis that he was following a rule directing the court to reason morally about those principles. Allan is surely correct to say that the decision in Liversidge depended on, or involved, moral reasoning, but that conclusion is perfectly compatible with the EFT. ${ }^{83}$ The fact that judges and lawyers frequently 'appeal[] to legitimacy ${ }^{184}$ in their judgments and arguments cannot not settle whether those appeals are to legal or (extra-legal) moral principles.

Take instead the case of Anisminic. ${ }^{85}$ Allan sees the decision as follows: 'In affirming the sovereignty of law-the subjection of powerful bodies to legal principles, enforced by independent courts- the House of Lords bolstered the sovereignty of Parliament'. ${ }^{86}$ Goldsworthy, by contrast, suggests that 'The judges' claim to be faithful to Parliament's intention was a 'noble lie' used to conceal judicial obedience'. ${ }^{87}$ In other words, he thinks that judges decided to disregard the settled law and decide the case on moral grounds. An-

\footnotetext{
${ }^{80}$ Allan targets a particularly simplistic all-or-nothing form of positivist adjudication, whereby judges either apply legal norms or they exercise unconstrained discretion. Dworkin is arguably guilty of the same thing in his work. For criticism, see, for instance, Joseph Raz, 'Dworkin: A New Link in the Chain', 74 Cal. L. Rev. 1103 (1986) 1115-1118; John Gardner, 'Legal Positivism: 5/12 Myths' 46 Am. J. Juris. 199 2001; Timothy Endicott, 'Adjudication and the Law' (2007) 27 OJLS 311-326; Nigel Simmonds, Law as a Moral Idea (Oxford: Oxford University Press, 2007), 196-197.

${ }^{81}$ See, most notably, the theory of adjudication in J. Raz, The Authority of Law: Essays on Law and Morality (Oxford: Clarendon Press, 1979) ch. 10.

${ }^{82}$ Allan considers such a rule at Sovereignty 21: '[the liberty-principle had] no relevance in dealing with executive measure by way of preventing a public danger' per Viscount Maugham 218.

${ }^{83}$ See Gardner above, $\mathrm{n} 72$.

${ }^{84}$ Sovereignty 210.

${ }^{85}$ Anisminic Ltd v Foreign Compensation Commission [1969] 2 AC 147.

${ }^{86}$ ibid 35.

${ }^{87}$ The Sovereignty of Parliament $\mathrm{n} 58$ above, 252. See, further, Goldsworthy, Parliamentary Sovereignty above n 31, 286.
} 
other theorist might argue that there was a pertinent rule directing judges to apply principles of the rule of law. ${ }^{88}$ Each of these options gives an explanation of the Anisminic decision; and we can suppose that supporters of these (and other) options genuinely believe that they have read the case correctly, and that others have read the case incorrectly. ${ }^{89}$ The difficulty here is that Allan gives us no reason to prefer his explanation over others (at least beyond asserting that other explanations belong to a different intellectual discipline). In the absence of some independent standard(s) of success for assessing one reading of a case against others, we face potentially unlimited readings of the same case, each reading being as viable as every other.$^{90}$ Imagine that a particularly resourceful researcher demonstrates that in every House of Lords decision in favour of the claimant (plaintiff) in 1969, the majority wore a wristwatch, or skipped breakfast, or walked to work. He may be convinced that one or other of these explanations tells us what truly happened in Anisminic. Allan gives us no reason to discount his explanation.

The strategic problems just described are symptomatic of a deeper philosophical problem with the way that supporters both of the IT and EFT sometimes attempt to meet one another's arguments. The problem, I suggest, is that both sides seek to establish descriptively that their thesis is correct. They suppose that if we study closely the way that judges and lawyers reason, and the way that the concept of law figures in people's social and political practices, then we will surely arrive at their thesis. ${ }^{91}$ Legal philosophers refer to this type of argument as conceptual analysis. ${ }^{92}$ This is not the place to attempt a comprehensive exposition or refutation of that type of argument, but I want to introduce just one way of attacking it. The nature of the attack should appeal to Allan - if not so readily to supporters of the EFT.

The starting point is that the content of the law must depend in some way on what Parliament has enacted, and on what judges have decided (which is to say that the phrase 'English law' is not simply another way referring, for instance, to the requirements of ideal justice, or

\footnotetext{
${ }^{88}$ This is one reading of Sir William Wade who contends that 'the courts have been forced to rebel against Parliament', applying 'a presumption that may override their constitutional obedience, namely that jurisdiction limits must be legally effective'. Wade, Administrative Law, 720-1, cited by Allan at Sovereignty $215 \mathrm{n}$ 17 .

${ }^{89}$ Another good illustration is the different readings of Riggs $v$ Palmer (1889) 115 NY 506, 22 NE 188 offered by Goldsworthy and Allan. See Goldsworthy, Parliamentary Sovereignty n 23 above, 284-285; Allan, Sovereignty 198-200.

${ }^{90}$ Mark Greenberg has called this the problem of 'global indeterminacy'. See M. Greenberg, 'How Facts Make Law' in Scott Hershovitz (ed.) Exploring Law's Empire, ch. 10. I have made this same type of argument in Stuart Lakin 'How to Make Sense of the HRA 1998: The Ises and Oughts of the British Constitution' (2010) 30 OJLS 399-417 (a review of Alison L Young, Parliamentary Sovereignty and the Human Rights Act (Oxford: Hart Publishing, 2009)).

${ }^{91}$ Proponents of this method characterize it in terms of non-moral evaluation. See, for instance, Joseph Raz, Ethics in the Public Domain: Essays in the Morality of Law and Politics (Oxford: Clarendon Press, 1994) 209. For a perceptive critique, see N W Barber, The Constitutional State n 51 above, ch. 1, especially 8-11. ${ }^{92}$ For an illuminating discussion of conceptual analysis, see N. Stavropoulos, 'Hart's Semantics' in Jules Coleman (ed.) Hart's Postscript Essays on the Postscript to the Concept of Law (Oxford University Press, 2001), ch. 3. For an admirable attempt to apply this type of descriptive method to English public law, see Peter Cane, 'Public Law in The Concept of Law' (2013) 33 OJLS 649-674, 654.
} 
the Ten Commandments). ${ }^{93} \quad$ To put this more abstractly, the law must depend, at least in part, on facts about British legal practice. It plausibly depends on descriptive facts about particular people's beliefs, intentions, utterances, texts and so on; and it plausibly depends on moral facts, for instance the values and principles that figure in statutes and precedents, or which are presupposed or entailed by them. All of these facts, let us say, are among the candidates for making the content of the law what it is; none of these facts either have automatic legal relevance or irrelevance. ${ }^{94}$ We need an argument, then, to show which putative law-making facts, configured in which way, are constitutive of the law, and which putative law-making facts are legally redundant. Crucially, that argument cannot be based on how particular people think, speak, act, or otherwise behave. The fact that judges and lawyers refer to - or implicitly rely on - certain standards (moral principles, rules, intentions, or whatever) in their judgments and arguments cannot non-question-beggingly make it the case that those standards are constitutive of the content of the law. This is because facts about what judges and lawyers do are themselves candidate law-making facts whose legal relevance requires an independent explanation.

That is a highly compressed summary of a complex argument. I shall not attempt to unpack it further here. Its upshot is that something other than putative law-making facts is needed to show why the law is based on empirical or moral facts (or on some combination of both). Allan can neither disprove the EFT nor prove the IT by pointing to the 'perspective' or 'point of view' of judges, lawyers and constitutional theorists (or indeed by citing Hart's aims in his writing). Another way of putting the point is that we cannot descriptively determine whether the EFT or the IT is correct. That may initially sound like Allan's own methodological stance, but the argument I am making works on a different level of analysis. We are not saying with Allan that the law cannot depend on empirical facts; we are saying that it cannot be descriptively true that law depends on empirical facts - just as it cannot be $d e$ scriptively true that law depends on moral facts. ${ }^{95}$ We need a non-descriptive argument to tell us which facts are constitutive of the law. The argument we need, I suggest, is an interpretative one. Someone attempting to make sense of the constitution must offer a moral theory to justify the legal relevance of some facts over others - a theory that can explain why the law imposes genuine moral obligations. ${ }^{96}$ That line of argument should appeal to Allan, but it is quite different to one he takes in Sovereignty. It supposes that the disagreement between proponents of EFT and IT is a substantive rather than a methodological one. It further supposes that descriptivists and interpretavists are all arguing from the same interpretative perspective: just as people who think that the content of the law depends on empirical facts rather than moral interpretation must argue interpretatively for that position, so people who think that the law depends on moral interpretation must argue interpretatively for that position. If these conclusions are correct, then we can push to one side our fears

\footnotetext{
${ }^{93}$ I am relying, in particular, on the argument in Greenberg above n 81. See, further, N Stavropoulos, 'Why Principles?' (unpublished) available at <http://papers.ssrn.com/sol3/papers.cfm?abstract_id=1023758 > accessed 9 September, 2014.

${ }^{94}$ Dworkin describes such facts as 'pre-interpretative'. See Dworkin Law's Empire above, n 12, 65-66.

${ }^{95}$ See R Dworkin, 'Hart's Postscript and the Character of Political Philosophy' (2004) 24 OJLS 1-37.

${ }^{96}$ Limitations of space preclude a substantial defence of this position. For Greeberg, moral values create a necessary 'rational connection' between facts and the law. Furthermore, the independence of values from legal practice prevents the problem of global indeterminacy. See Greenberg above $n$ 81. For a competing view, see J Raz, 'Two Views of the Nature of the Theory of Law: A Partial Comparison' in Jules Coleman, Hart's Postscript n 92 above..
} 
about a methodological impasse in public law. Instead of assertion and counter-assertion about who is working within the correct discipline, we can expect supporters of the IT and EFT to construct rival justifications for British constitutional practice. That is precisely the character of disagreement about law and the constitution envisioned by Ronald Dworkin in his groundbreaking work on interpretation. Allan, I think, has regrettably - and perhaps unwittingly - reverted to the very type of conceptual reasoning that Dworkin sought to resist. $^{97}$

What might an EFT interpretation of the constitution look like? There are numerous possibilities. The most likely justification for an orthodox interpretation of the constitution is a 'political constitutionalist' conception of democracy, the rule of law and the separation of powers. I shall consider this type of interpretation in some depth in the next section. Alternatively, supporters of the orthodoxy might recast Goldsworthy's Hartian defence of parliamentary sovereignty as an interpretative theory. ${ }^{98}$ The argument would be something like this: that the values of maintaining constitutional stability and averting constitutional crisis, and the value of enabling people to reflect on whether the law is worthy of obedience, make it the case that the powers of parliament and courts depends on the empirically ascertainable beliefs of most officials. $^{99}$ As Allan rightly says, however, it is highly doubtful whether one could ever find the necessary consensus among officials to support such an interpretation. ${ }^{100}$ A more promising EFT interpretation of the constitution is one based on the work of Raz and taken up by Barber. ${ }^{101}$ Here is a sketch of that 'law as authority' interpretation:

(Law as Authority) The value of guiding individuals to act in accordance with right reason makes it the case that legal norms must be capable of being obeyed or followed. The identification of a legal norm therefore cannot require controversial moral judgment. Laws must take the form of empirically ascertainable directives, rules or official utterances. ${ }^{102}$

What stands out about this interpretation when placed alongside Allan's is the starkly contrasting conceptions of law and the rule of law. For Allan, law - understood as thick con-

\footnotetext{
${ }^{97}$ See, in particular, Dworkin, Law's Empire n 4 above, chs. 1 and 2.

${ }^{98}$ Goldsworthy attempts such an interpretative defence himself, but he fundamentally misunderstands the interpretative method. He assumes that the '...interpretive methodology is construed...as an attempt to clarify and harmonise the principles actually accepted by British legal officials'. See Goldsworthy, The Sovereignty of Parliament n 50 above, 254 and generally 253-259. But the interpretative methodology is an attempt to determine whether the content of the law depends on the acceptance of legal officials (and, more generally, whether the content of the law depends on empirical and/or moral facts)

${ }_{99}$ See Goldsworthy The Sovereignty of Parliament, above n 50, 241-246. Dworkin considers (but ultimately rejects) a theory of this sort which he calls 'conventionalism'. See Dworkin, Law's Empire n 12 above, ch. 4. For a moral defence of legal conventionalism based on the values of good governance and interinstitutional respect, see Dimitrios Kyritsis, 'What is good about legal conventionalism?' (2008) 14 Legal Theory 135-166, especially 155-159. For development of the type of political arguments for the EFT adumbrated in the main text above, see Liam Murphy, 'The Political Question of the Concept of Law' in Jules Coleman (ed.) Hart's Postscript n 92 above.

${ }^{100}$ Sovereignty 156.

${ }^{101}$ See Raz n 91 above, especially chs. 9 and 10; Barber $n 51$ above.

${ }^{102}$ For an intriguing elaboration (and rejection) of this interpretative recasting of Raz's work, see Ronald Dworkin, Justice in Robes n 12 above, 198-212 and 227-331. See further N Stavropoulos n 93 above, especially 33-36. Raz explicitly disassociates his authority-based theory from the interpretative method. See J. Raz, Ethics in the Public Domain: Essays in the Morality of Law and Politics (Oxford: Clarendon Press, 1994) 301, footnote 35.
} 
ception of the rule of law - is sovereign. For Raz, on the other hand, law is an instrumental tool in a state or constitution. ${ }^{103}$ Its narrow purpose is to communicate authoritative reasons for action to individuals. It does not encapsulate any theory of justice or rights, and it is distinct from the 'rule of law'. The rule of law - understood in a thin, formal, sense - he contends, has prima facie force only: 'it is just one of the virtues by which a legal system may be judged and by which it is to be judged'. ${ }^{104}$ The law will achieve its guidance function more efficiently if it satisfies the requirements of the rule of law, but that value might be outweighed by other reasons or values. ${ }^{105}$ As if to turn every last element of Allan's theory inside out, Raz denies that judges have a general duty to enforce the law; and he denies that individuals have a general obligation to obey the law.

In line with his general approach in Sovereignty, Allan seeks to reject this Razian account on conceptual grounds. He condemns the division between law and the rule of law as a 'questionable dualism'. ${ }^{106}$ And he confidently proclaims that 'our general ideal of law' ${ }^{107}$ is such that legal argument is necessarily a form of moral argument (just as Raz and others confidently proclaim that legal argument is necessarily not a form of moral argument). My aim in this section has been to steer Allan (and others) away from these types of dead-end conceptual exchanges. The view I have put is that the disagreement between Allan, Raz, Hart/Goldsworthy, and others concerns which theory of law and government makes best moral sense of British legal and constitutional practice. How we determine the content of the law and the constitution in Britain, and how we view the relationship between law and adjudication, law and the rule of law, law and convention, and so on, must ultimately depend on how we resolve these deep interpretative disagreements. ${ }^{108}$ Law (or legality) is 'sovereign' only in the very limited sense that every constitutional theory is predicated on some competing understanding of this concept. ${ }^{109}$

\section{INTERPRETATION, COMMON LAW CONSTITUTIONALISM, AND THE RULE OF LAW AS INDEPENDENCE}

My second objection to Sovereignty goes to the relationship between the IT and Allan's theory of the rule of law and common law constitutionalism. The question is whether he means to offer his theory as the only possible interpretation of the constitution, or as the best one. This is the ambiguity in the meaning of the IT that I flagged above. There is textual evidence to support both understandings. My contention is that the first understanding is philosophically flawed: it negates the very idea of interpretation. The only way that Allan can vindicate his theory is by adopting the second understanding. His difficulty then, how-

\footnotetext{
${ }^{103}$ See Raz, n 81 above, 225-6.

104 ibid 228.

105 ibid 226.

${ }_{106}$ Sovereignty 109.

107 ibid 134.

${ }^{108}$ Paul Craig (n 66 above) expertly maps the positivist and anti-positivist position on these types of questions, but, like Allan, I think he fails to appreciate the interpretative sense in which the two positions compete. See, further, Sovereignty 334-335.

${ }^{109}$ See, Stuart Lakin, 'Debunking the Idea of Parliamentary Sovereignty: The Controlling Factor of Legality in the British Constitution' (2008) 28 OJLS 709-34.
} 
ever, is that British constitutional practice arguably lends itself more readily to a 'political' constitutionalist interpretation than a 'legal' or 'common law' constitutionalist one.

In order to get to these conclusions, we first need to build a fuller picture than I have so far given of Allan's constitutional theory - and the way he links his theory to the IT. A telling place to begin is his claim that the IT necessarily 'excludes any absolutist doctrine of parliamentary sovereignty'. ${ }^{110}$ The only permissible interpretation of parliamentary power is one of limited or legitimate authority. This has significant implications for the role of courts. He denies that there is any meaningful distinction between 'weak' and 'strong' judicial review. ${ }^{111}$ The common law constitution, he says, is distinct from both arrangements. Courts have a duty to interpret statutes in line with equal dignity and basic common law rights; ${ }^{112}$ and they will ordinarily be able to do so (as exemplified by Anisminic). ${ }^{113}$ But the rule of law requires that they possess the power to quash a measure where no such interpretation is available (as with the Blue Eyed Babies Act). ${ }^{114}$ Allan denies that he is pitting a legal constitution against a rival political constitution. He insists that every account of the constitution is both legal and political in so far as it must include some coherent account of the rule of law and the separation of powers. ${ }^{115}$ It is for courts to determine, case by case, the requirements of the rule of law, and the correct distribution of powers.

The views just described make for a fascinating take on the HRA 1998. For Allan, section 3 of the Act merely replicates the pre-existing common law order. ${ }^{116}$ Common law reasoning involves precisely the same balancing of relevant considerations. It embodies the proportionality test. $^{117}$ It therefore should not have mattered in the ex parte Smith case, he says, that the European Convention on Human Rights (ECHR) had not been incorporated: ${ }^{118}$ 'The court's appraisal... fell short of what was necessary to protect the basic rights in issue'. 119 His view on section 4 of the Act is equally revealing. His general attitude is that the measure is an 'interpretative failure'. ${ }^{120}$ It was too weak in the $A$ case - the House of Lords should have invalidated or ignored the statute. ${ }^{121}$ And it was an 'abdication of responsiblity' for judges to grant a declaration in Bellinger. ${ }^{122}$ The logical endpoint of Allan's theory is that the HRA is practically otiose in Britain. If Parliament were to repeal the Act, 'the underlying common law constitution would remain untouched...' 123 More broadly, he

\footnotetext{
${ }^{110}$ Sovereignty 166.

111 ibid 37.

112 ibid, for example, at 114.

113 ibid 230.

${ }^{114}$ ibid, for example, at 140-141.

115 ibid 305

${ }^{116}$ ibid ch. 5. See, further, TRS Allan, 'Parliament's Will and the Justice of the Common Law: The Human Rights Act in Constitutional Perspective' (2006) 59 CLP 27-50.

${ }^{117}$ Sovereignty chs. 6 and 7.

${ }_{118}^{118 i d}$ 245. Rv Ministry of Defence, ex $p$ Smith [1996] QB 517.

119 Sovereignty 255.

${ }^{120}$ ibid 202.

${ }^{121}$ ibid 116-117 and 185. A v Secretary of State for the Home Department [2004] UKHL 56. Allan offers a possible way in which the House of Lords might have used of HRA s. 3 in $A$ at 117.

${ }^{122}$ Sovereignty 319-321. Bellinger $v$ Bellinger [2001] EWCA Civ 1140.

${ }^{123}$ Sovereignty 324.
} 
doubts whether any form of Bill of Rights can make a difference to common law legal systems. $^{124}$

We now come to our objection. Allan assures us throughout Sovereignty that he means to advance his theory of the rule of law and common law constitutionalism as an interpretation of the constitution 'as it is' rather than as he would invent it. ${ }^{125}$ How do we distinguish interpretation from invention? For Dworkin, an interpreter must attempt to achieve an equilibrium between the 'standing features' of a particular legal and constitutional practice, and the moral theory that best justifies those features: moral theory partly determines the content of the practice, and the standing features of the practice constrain the available range of moral theories. ${ }^{126}$ An interpreter of the British constitution, then, will need both to justify and explain (or explain away), for instance, the doctrine of precedent, legislation, statutory interpretation, and the collected propositions of law and the constitution generally held to be true. $^{127}$ An inventer of a constitution, by contrast, will have no genuine regard for the standing features of British constitutional practice. He will choose his moral theory according to its independent appeal alone. He will then propose a constitutional practice that matches his moral theory - or he will chop and change an existing practice until it approximates to his theory. ${ }^{128}$

Despite Allan's assurances to the contrary, his theory of common law constitutionalism and the rule of law often has more of a feel of invention than interpretation about it. Take the following type of recurrent phrase:

'When we [interpret the constitution] - we are guided by a vision of the rule of law as a scheme of justice, implicit in our existing constitutional arrangements, at least when these are favourably regarded. Even if the law on many questions falls some way short of the ideal of legality, preserving a genuine equality of freedom, we try to bring it as close as we can'. ${ }^{129}$

If by 'implicit in our existing constitutional arrangements', he means whichever 'favourably regarded' conception of the rule of law, democracy, the separation of powers, justice and so forth is instantiated in British constitutional practice, then we will plausibly be in the realm of interpretation. But Allan has rather fixed, preconceived ideas about what is 'implicit'. He thinks that a specific set of rule of law values, understood in a specific way are implicit; he thinks that specific fundamental common law rights are implicit; and he thinks that a

\footnotetext{
${ }^{124}$ ibid 175-176 and, generally, ch. 8. Allan follows Hayek in this view. See F A Hayek, Law, Legislation and Liberty (London: Routledge \& Kegan Paul, 1932) 109-10.

${ }^{125}$ Sovereignty Appendix and, in particular, 340-349.

${ }^{126}$ Dworkin, A Matter of Principle n 12 above, ch. 6; Law's Empire n 12 above, ch. 3; Sovereignty 341-342.

${ }^{127}$ Dworkin, Law's Empire op. cit. 90-91.

${ }^{128}$ This is arguably the very project that motivates some political constitutionalists. Bellamy has described his republican theory of political constitutionalism as an 'ideal type'. He concedes that the British constitutional practice may not be compatible with his political theory, but he attempts to show ways in which it 'could be so'. See R. Bellamy 'Political constitutionalism and the Human Rights Act' (2011) I.J.C.L. 86111, 89-90. Similarly, Gee and Webber use political constitutionalism as a 'normative model' or 'exemplar' with which to make sense of a 'real world constitution'. See Graham Gee and Gregoire C N Webber, 'What Is a Political Constitution?' (2010) 30 OJLS 273-299, 291-292.

${ }^{129}$ Sovereignty 91.
} 
specific division of institutional powers is implicit. ${ }^{130}$ The task he seems to assign to the interpreter, then, is to bring British legal and constitutional practice 'as close as we can' to these essential features of the rule of law and constitutions. If this is Allan's position, then it is not obviously an interpretative one. We said above that interpretation is a twoway process between constitutional practice and moral theory. Allan's argument runs in one direction only. In the manner of a constitutional inventer, he uses his theory of the rule of law as independence as a 'moral filter': ${ }^{131}$ any part of British constitutional practice that cannot be brought into line with a 'genuine equality of freedom' is deemed to be unlawful or unconsitutional. Indeed, this is the very task that he reserves for judges in his account of constructive statutory interpretation. ${ }^{132}$ The existing practice, on this approach, plays no genuine part in determining the correct theory of the rule of law and other political values.

Allan's views on the HRA perhaps reinforce this sense of invention over interpretation. Let us begin with some reasonably uncontentious observations about the Act and its implementation. Parliament made a deliberate choice to draft it in the way that it did. It might have adopted any number of other forms of rights protection, including one that gives judges a power to invalidate statutes. Courts have painstakingly set out to make sense of its specific scheme, and to decide cases in accordance with it - the Supreme Court has continually grappled with the questions of when to use section 3 and when to use section 4, and how to adapt the traditional Wednesbury standard of judicial review to the Strasbourg proportionality test. The effect of Allan's arguments on the HRA - and on Bills of Rights in general - is that a legislative decision to create a particular framework of rights protection, and the attempt by courts to work within that framework, can have no impact on the law. People will have the same legal rights, duties and powers of individuals and institutions irrespective of the particular institutional decisions and practices one finds. Once again, this approach fails to capture the dynamic of interpretation - an interaction between the object of interpretation (the practice) and its purpose or value. It can instead be seen as an attempt to 'homogenize' all constitutions without having regard for their different legal and political practices, history and traditions. ${ }^{133}$

Let us now consider the second, alternative reading of the IT. What if we read Allan as arguing that his moral theory of the rule of law and common law constitutionalism makes better moral sense of the 'standing features' of British constitutional practice than other 'schemes of justice'? On this reading - which is certainly the one that comes through most strongly in Sovereignty - Allan is doing precisely what an interpreter qua interpreter must: he is giving an account of British constitutional practice that matches his account of legitimacy. But I think another difficulty now stands in his way. Many of the salient features of the practice point towards a political constitutionalist conception of democracy, the rule

\footnotetext{
${ }^{130}$ Cf Craig, 'Constitutional Foundations, the Rule of Law and Supremacy' [2003] PL 92-111. See , further, Goldsworthy, Parliamentary Sovereignty n 31 above, 88

${ }^{131}$ See N Stavropolous, 'Legal interpretavism' available at http://plato.stanford.edu/entries/law-interpretivist/ accessed September 09, 2014.

${ }^{132}$ Craig objects in a similar vein that Allan assimilates constructive interpretation to his own theory of the rule of law. See Paul Craig 'The Common Law, Shared Power and Judicial Review' (2004) 24 OJLS 237, 241-242.

${ }^{133}$ See Goldsworthy, Parliamentary Sovereignty n 31 above, ch. 4. See, further, W. Sadurski, 'Judicial Review and the Protection of Constitutional Rights' (2002) 22 OJLS 275.
} 
of law and the separation of powers. By this, I broadly mean a political theory that favours a majoritarian model of democracy over a right-based model; one that conceives of the rule of law as a narrow, formal principle; one that favours the legislature over courts as the primary forum for resolving disagreements about rights and the constitution; and one that seeks to minimise the adjudicative role of judges. In sum, a political theory that plausibly justifies parliamentary sovereignty and other tenets of British constitutional orthodoxy. ${ }^{134}$ We have already considered some of the evidence in this direction. The declaration of incompatibility is arguably designed to facilitate dialogue between the courts and parliament on the meaning and content of rights. ${ }^{135}$ It can be seen as way of allowing citizens, via their elected representatives, to participate in decisions about their own rights. ${ }^{136}$ On this view, the declarations in Bellinger, $A$ and elsewhere were not 'interpretative failures' or 'abdications of responsibility', but legitimate attempts to honour the prevailing political theory of the day. ${ }^{137}$ If Parliament were in future to introduce a British Bill of Rights with a 'democratic override' provision, we could reasonably expect courts to enforce that measure on the same basis.

More evidence for a 'political' reading of the constitution can arguably be found in the very case that Allan makes central to his common law constitutionalist interpretation of the constitution, Prolife. ${ }^{138}$ His view is that the Court of Appeal and the minority in the House of Lords correctly read the 'taste and decency' provision of the Broadcasting Act in the light of the constitutional principle of freedom of speech. He thinks that the majority in the House of Lords erred in attempting to give effect to the literal meaning of the statute. Their decision reflected a 'narrow, authoritarian vision of the legal order' rather than one that made judges the 'servants of the constitution or legal order'. ${ }^{139}$ He concludes that 'if we think that the law and liberty are necessarily connected values, regulating the permissible boundaries of governmental power, we will prefer the judgment of the Court of Appeal. ${ }^{140}$ The difficulty here, once again, is that our role as interpreters is not to impose our preferred moral theory on judicial decisions (and other parts of the constitution); it is to identify the moral theory that underpins those decisions. The House of Lords decision can plausibly be understood as promoting Parliament's right to balance freedom of expression with public policy. The majority explicitly saw things in this way. ${ }^{141}$ Of course, it is open to Allan to contend that political readings of constitutional practice are (interpretatively) unconvincing, or that particular judicial decisions - those potentially favourable to political constitutionalists - are interpretative 'mistakes' given the overall scheme of principle underlying the constitution. The suspicion, at times, is that he is unwilling to entertain the possibility of a political reading of the cases.

\footnotetext{
${ }^{134}$ See, generally, R Bellamy n 23 above.

${ }^{135}$ See, for instance, Young n 90 above, chs. 4-6.

${ }^{136}$ See, J. Waldron, Law and Disagreement, (Oxford: Oxford University Press, 1999), especially ch. 11.

${ }^{137}$ Kavanagh takes this type of view of Bellinger in, Aileen Kavanagh Constitutional Review under the UK Human Rights Act (Cambridge: Cambridge University Press, 2009), 137. See also Helen Fenwick and Gavin Phillipson, 'Covert Derogations and Judicial Deference: Redefining Liberty and Due Process Rights in Couterterrorism Law and Beyond' (2011) 56 McGill LJ 863-918 (arguing that a declaration of incompatibility was more appropriate in the control order cases under the Prevention of Terrorism Act 2005).

${ }^{138} R$ (Prolife Alliance) v British Broadcasting Corporation [2002] EWCA Civ 297, [2003] UKHL 23.

${ }^{139}$ Sovereignty 27-29.

140 ibid 31.

${ }^{141}$ Above n 138, para. 15.
} 
Two further matters remain for brief discussion. First, we noted above Allan's view that legal and political practice are 'too intertwined and interdependent to sustain [a distinction between the legal and political constitution]. ${ }^{142}$ I have attempted to convey a very different view in this review article, namely that there is scope for highly distinct legal and political interpretative theories of constitution, based respectively on non-positivist and positivistinspired theories of law and adjudication (or the separation of powers). These contrasting theories, I have suggested, can compete to explain cases such as Prolife and Liversidge. My own view, then, is that the political/legal constitution distinction is an important and under-explored one.

The second matter relates closely to the first. Allan will no doubt object to a political constitutionalist reading of Prolife and other cases on the basis that political constitutionalism has no coherent theory of adjudication. ${ }^{143}$ He will deny that statutory texts have a literal meaning or a meaning that was intended by parliament. He will insist that there can be no sharp divide between the 'strict legalism' of a statutory text and 'constitutional principle in the courts at the most fundamental level'. ${ }^{144}$ It may well be that there are difficulties with some of leading attempts by political constitutionalists to carve out a role for judges. ${ }^{145}$ I have suggested above, however, that there are a range of sophisticated EFT theories of adjudication available to political constitutionalists. On a superficial level, the gap between Allan's own favoured theory and these EFT theories may be far smaller than he supposes. ${ }^{146}$

\section{CONCLUSION}

Sovereignty is the most developed and powerful defence of common law constitutionalism and the most devastating critique of constitutional orthodoxy - to date. It is essential reading for judges, lawyers, academics and students. Part of its great value lies in Allan's comprehensive elaboration of these different visions of the constitution, and in his dissection of the many public law debates that surround them. It is difficult to think an area of British constitutional practice and theory that escapes his detailed attention. This review has barely touched the surface of his wide ranging analyses. The most significant contribution of the book, however, is the way that Allan explicitly connects mainstream UK public law to debates in legal and political theory. He demonstrates that every theory or doctrine

\footnotetext{
${ }^{142}$ Sovereignty 57.

${ }^{143}$ See, for instance, Sovereignty ch. 8.

${ }^{144}$ Jackson [2005] UKHL, 56, para 101. See Sovereignty 143-144. David Dyzenhaus adopts a similar view to this in much of his work. See, for instance, Dyzenhaus, 'The Incoherence of Constitutional Positivism' in Grant Huscroft (ed.), Expounding the Constitution Essays in Constitutional Theory 138-161. Both Allan and Dyzenhaus, I think, underestimate the explanatory potential of contemporary positivist theories of law and adjudication (understood as interpretative theories).

${ }^{145}$ See, further, Paul Craig, 'Political Constitutionalism and the Judicial Role: A Response' (2011) 9 I.CON 112-13 (a response to A Tomkins, 'The Role of the Courts in the Political Constitution', 60 Univ. Tor. L.J. 1 (2010).

${ }^{146}$ In particular, positivist theories of adjudication employ the same fluid distinction between law-applying and law-making as one finds in the theories of Allan and Dworkin. See, for example, J. Raz, 'Dworkin: A New Link in the Chain' $\mathrm{n} 80$ above, 1117.
} 
in public law inescapably assumes a position in these more abstract debates. And he argues emphatically that only the anti-positivist, interpretavist position can be sustained.

In presenting legal and constitutional argument as a species of moral argument, Allan has brought to British constitutional scholarship what Dworkin brought to US constitutional scholarship. To borrow a fitting phrase, he has helped British constitutional theory to 'find its soul. ${ }^{147}$ My aim in this review has not been to counter Allan's interpretative project, but to suggest some ways in which he can strengthen it, and remain faithful to it. In particular, I have argued that his interpretative commitments demand that he sees positivist accounts of the constitution as rival interpretations to his own rule of law as independence interpretation. This is to say that it is morally controversial whether, or in what sense, law is sovereign in the constitution. I have also suggested that the interpreter of the British constitution (and of constitutions in general) must show a greater sensitivity to local practices and principles than one perhaps finds in Sovereignty. Specifically, I have argued that Allan needs to be more open to a 'political' reading of the constitution. When understood in these ways, Sovereignty has the potential to precipitate an exciting new phase in public law - and indeed in legal and constitutional theory.

${ }^{147}$ See Rebecca L. Brown, 'How Constitutional Theory Found its Soul: the Contributions of Ronald Dworkin' in Scott Hershovitz (ed), Exploring Law's Empire (Oxford University Press, 2006). 